Cahiers $d u$ MONDE RUSSE

\section{Cahiers du monde russe}

Russie - Empire russe - Union soviétique et États indépendants

$49 / 4 \mid 2008$

Destins individuels et terreur. Jeunesse dans la société post-stalinienne

\title{
Aleksandr Shliapnikov's purge from the soviet communist party in 1933
}

\section{BARBARA C. ALLEN}

\section{OpenEdition}

\section{Journals}

Édition électronique

URL : https://journals.openedition.org/monderusse/9495

DOI : 10.4000/monderusse. 9495

ISSN : $1777-5388$

Éditeur

Éditions de l'EHESS

Édition imprimée

Date de publication : 28 décembre 2008

Pagination : 559-580

ISBN : 978-2-7132-2197-2

ISSN : $1252-6576$

Référence électronique

BARBARA C. ALLEN, «Aleksandr Shliapnikov's purge from the soviet communist party in 1933 », Cahiers du monde russe [En ligne], 49/4 | 2008, mis en ligne le 01 janvier 2008, consulté le 02

septembre 2022. URL : http://journals.openedition.org/monderusse/9495 ; DOI : https://doi.org/ 10.4000/monderusse.9495 


\section{ALEKSANDR SHLIAPNIKOV'S PURGE FROM THE SOVIET COMMUNIST PARTY IN $1933 *$}

Before the Russian Revolution and during the early years of the Soviet era, Russian Bolshevism was a diverse political movement in which Lenin's views were not hegemonic. ${ }^{1}$ The Russian Civil War provided the context in which the coercive and centralizing variant of Leninist Bolshevism that became Stalinism achieved ascendancy. ${ }^{2}$ Iosif Vissarionovich Stalin's faction prevailed over those of his political rivals by 1929, but even in the 1930s, there were still some Russian Communists for whom "speaking Bolshevik" did not necessarily mean "speaking Stalinist."3 Perhaps they were more prevalent among the older generation of party members than the

\footnotetext{
* Research for this article was made possible by a Fulbright-Hays Doctoral Dissertation Research Abroad fellowship and by a grant from the International Research \& Exchanges Board (IREX). An earlier version of this article was presented to the 2007 convention of the American Association for the Advancement of Slavic Studies. The author is grateful to La Salle University for providing funds to attend the convention. The author also greatly appreciates helpful suggestions for revisions provided by Anna Krylova, Simon Pirani and anonymous reviewers for this journal.
}

1. Robert C. Williams, The Other Bolsheviks: Lenin and His Critics, 1904-1914(Bloomington, IN: Indiana University Press, 1986) detailed the diversity among pre-revolutionary Bolsheviks. Alexander Rabinowitch examined disagreements among Bolsheviks in The Bolsheviks Come to Power: The Revolution of 1917 in Petrograd (New York: W.W. Norton \& Co., 1976).

2. A. Rabinowitch examined how objective circumstances shaped Bolshevik decision-making in The Bolsheviks in Power: The First Year of Soviet Rule in Petrograd (Bloomington, IN: Indiana University Press, 2008), while Donald J. Raleigh showed in Experiencing Russia's Civil War: Politics, Society, and Revolutionary Culture in Saratov, 1917-1922 (Princeton, NJ: Princeton University Press, 2002) how the Civil War set the stage for Stalinism to prevail over Bolshevik alternatives to it.

3. Stephen Kotkin equated "speaking Bolshevik" with Stalinist discourse in Magnetic Mountain: Stalinism as a Civilization (Berkeley-Los Angeles, CA: University of California Press, 1997). Igal Halfin saw no essential differences in the discourses of Stalin and his political opponents within the Communist Party in Terror in My Soul: Communist Autobiographies on Trial (Cambridge, MA: Harvard University Press, 2003). 
younger. ${ }^{4}$ Aleksandr Gavrilovich Shliapnikov, an Old Bolshevik from among the Russian metalworkers, was one of these. Born in 1885 into an Old Believer family in Murom, Shliapnikov became a revolutionary in 1901. He lived abroad from 1908 to 1916 and worked closely with Lenin during World War I, sometimes disagreeing with him. During World War I, he provided the chief organizational link between the Bolshevik Central Committee (CC) abroad and the Bolshevik party organization within Russia. From 1917 to 1921, he chaired the Russian Metalworkers' Union; he was Commissar of Labor in the first Bolshevik government. In 1919-1921 he led the Workers' Opposition (WO), a movement of Communist trade union leaders who advocated that trade unions control the economy and that industrial workers prevail in party leadership organs. At the Tenth Party Congress in March 1921, the WO was defeated and Shliapnikov became stigmatized as an oppositionist. Party leaders removed him as chair of the Metalworkers' Union, but he continued to receive important work assignments in the 1920s. After 1921, the Party Central Control Commission (CCC) repeatedly investigated Shliapnikov for oppositionism, but he was purged from the party for the first and only time in 1933; the main charge was “double-dealing" (dvurushnichestvo). In the 1933 purge, party members were only subject to expulsion, not execution as in the Terror of 1936-38. Nevertheless, in some ways the 1933 purge foreshadowed the later terror. This paper investigates Shliapnikov's purge from the party, in which purge commission members perceived Shliapnikov's "soul" to be incompatible with the Stalinist ideal and Shliapnikov defended himself by demanding "liberal" standards of evidence and investigation and by employing humor to subvert the charges against him. 5

The 1933 party purge took place against the backdrop of famine in the countryside, resistance among rural communists to the 1932 grain collection, and a rise in worker unrest that posed a potential danger to the Stalinist leadership's claim to rule in the name of the proletariat. In 1932 there were discovered three oppositional groups (the Riutin group, a group allegedly associated with Lev Davidovich Trotskii, and the Eismont-Tolmachev-Smirnov group) that expressed discontent within the party over collectivization. Stalinist party leaders feared that private expressions of discontent would lead to factionalism. ${ }^{6}$ At a CC plenum in January 1933, Stalin called for "vigilance" toward "remnants of moribund classes" that had "wormed their way" into industry, collective farms, and government and that threatened to "provide fuel for a revival of the activities of defeated groups of

4. Jochen Hellbeck examined the Stalinist mindset in formation among Soviet diarists in his Revolution on My Mind: Writing a Diary under Stalin (Cambridge, MA: Harvard University Press, 2006).

5. Anna Krylova discusses Western historians' conceptualization of the "liberal subject" in Soviet Russia in "The Tenacious Liberal Subject in Soviet Studies," Kritika: Explorations in Russian and Eurasian History, 1, 1 (Winter 2000): 1-28.

6. Charters Wynn, "The 'Right Opposition' and the 'Smirnov-Eismont-Tolmachev Affair'," in Paul R. Gregory and Norman Naimark, eds., The Lost Politburo Transcripts: From Collective Rule to Stalin's Dictatorship (New Haven, CT: Yale University Press, 2008), 97-117; Jeffrey Rossman, Worker Resistance to Stalin: Class and Revolution on the Shop Floor (Cambridge, MA: Harvard University Press, 2005). 
the old counter-revolutionary parties," among which he included Trotskyists and "right deviationists." According to April 1933 guidelines, the purge was to target "double dealers," "alien elements," and other categories; it was scheduled to begin in Moscow and some other areas on June $1^{\text {st }} .8$ The 1933 purge "expelled about 18 percent of the party's members." The largest single group targeted consisted of "inactive" party members, while former oppositionists supposedly were a small minority. ${ }^{9}$ Official categories, however, most likely failed to reveal the extent of the purge's political character. The party had already established a pattern of using the purges to cull dissenters. In the 1920s purges, quotas were assigned and categories devised in order to "camouflage the charge of Trotskyism." Therefore, it was difficult to determine the actual reasons for purging individuals based on the statistical categories provided by the party. ${ }^{10}$ Shliapnikov had helped to organize the 1921 purge, but had not been able to prevent the purging of his political supporters, under cover of other charges.

Shliapnikov worked in Gosudarstvennyi komitet po planirovaniiu (Gosplan) RSFSR in 1933 and was purged from its party cell in June 1933. He appealed to Stalin, to the purge commissions of Bauman raion (district) and Moscow oblast (region), and to the Central Purge Commission. Stalin deflected his appeal, but each commission interviewed him anew. Shliapnikov insisted on recounting his work on behalf of the party; he refused to make a wholesale condemnation of his previous stands or to characterize them as linked. He demanded evidence for the charges against him, gave sarcastic retorts, and made ironic jokes. Shliapnikov's behavior during the purge was neither outright resistance, nor abject submission, but was nuanced and multifaceted, just as his political behavior had been during other episodes of his life. His dialogue with purge commission members reflected an alternative understanding of party spirit (partiinost') and a stance that lay somewhere between resistance and compliance. ${ }^{11}$ Shliapnikov wanted to remain within the party, but not at the cost of smearing his political past, and he held out hope that in the long term the revolutionary workers' movement would outlive the

7. Hiroaki Kuromiya, Stalin: Profiles in Power (Harlow: Pearson Education Limited, 2005), 110.

8. "On the Party Purge: 28 April, 1933," in Robert H. McNeal, ed., Resolutions and Decisions of the Communist Party of the Soviet Union, vol. 3: The Stalin Years, 1929-1953 (Toronto: Univ. of Toronto Press, 1974), 124-129. Central Purge Commission members included Ia.E. Rudzutak, L.M. Kaganovich, S.M. Kirov, N.I. Ezhov, E.M. Iaroslavskii, and M.F. Shkiriatov. See J. Arch Getty, Origins of the Great Purges: The Soviet Communist Party Reconsidered, 1933-1938 (Cambridge: Cambridge University Press, 1985), 51.

9. J. Arch Getty and Oleg V. Naumov, The Road to Terror: Stalin and the Self-Destruction of the Bolsheviks, 1932-1939 (New Haven, CT: Yale University Press, 1999), 127-128 (depending on a 1971 Soviet source). See also Getty, Origins of the Great Purges: The Soviet Communist Party Reconsidered, 1933-1938 (Cambridge University Press, 1985).

10. Michael David-Fox, Revolution of the Mind: Higher Learning among the Bolsheviks, 1918-1929 (Ithaca, NY: Cornell Univ. Press, 1997), 158.

11. For essays on the suitability of the term "resistance" to characterize views, stances, and behavior of individuals and groups in Russian and Soviet political history, see Michael DavidFox, Peter Holquist, Marshall Poe, eds., The Resistance Debate in Russian and Soviet History (Bloomington, IN: Slavica Publishers [Kritika Historical Studies, 1], 2003). 
distortions of the 1930s. During these months, he suffered from 50\% hearing loss, which limited his ability to respond to charges against him and contributed to his obvious exhaustion by the end of each purge session.

Transcripts of Shliapnikov's dialogue with purge commission members at each level were preserved in Shliapnikov's Party Control Commission file in Rossiiskii gosudarstvennyi arkhiv sotsial'no-politicheskoi istorii (RGASPI). Other relevant records include those of the Gosplan RSFSR party cell in Tsentral'nyi arkhiv obshchestvennykh dvizhenii goroda Moskvy (TsAODM) and materials confiscated from Shliapnikov and held in Tsentral'nyi arkhiv Federal'noi Sluzhby Bezopasnosti (TsA FSB). ${ }^{12}$ Unfortunately, these materials do not provide a complete picture of the way in which the party planned and carried out the purge. Central Control Commission protocols and internal memoranda (RGASPI, fond 589), which would provide a much better understanding of the purges and other political developments within the Party, are still off limits to academic researchers. Nevertheless, the transcripts of Shliapnikov's purge sessions offer revealing clues about the internal dynamics of the purge.

Before analyzing Shliapnikov's purge sessions, this paper will discuss several other significant episodes in his political life in 1932 and 1933. These are important for understanding his purge. Shliapnikov's exclusion from the party was preceded in early 1932 by condemnation and suppression of his historical works on 1917, in late 1932 by a political investigation of his friend and political ally Sergei Pavlovich Medvedev, by Shliapnikov's implication in a couple of minor scandals related to housing in late 1932 and early 1933, and in early 1933 by accusations that he made an anti-party speech at a meeting of the Gosplan RSFSR party cell.

\section{Shliapnikov's memoirs}

Shliapnikov's historical memoirs of 1917 (Kanun semnadtsatogo goda and Semnadtsatyi god) were published in several volumes and in several editions in the 1920 s and up to 1931 . They were important sources about the revolution for both Western and Soviet historians. Critics attacked them on several occasions in the 1920s, ${ }^{13}$ but they were banned only after Stalin sent a letter to Proletarskaia Revoliutsiia in October 1931 outlining an exclusively ideological approach toward writing history. ${ }^{14}$ The campaign against Shliapnikov's books began with hostile

12. Shliapnikov's daughter gave me permission to conduct research among her father's materials in the central FSB archive and in the Party Control Commission files. Irina Medvedeva gave me similar permission to access relevant files on her father, Sergei Pavlovich Medvedev, a co-leader of the Workers' Opposition. Of fifty-six volumes of material on the 1935-1937 case of the Workers' Opposition, Moscow group, in the archive of the FSB, I have examined fourteen; I was not allowed access to the other forty-two without permission of the relatives of accused persons.

13. Larry E. Holmes, "Soviet Rewriting of 1917: The Case of A.G. Shliapnikov," Slavic Review, 2 (1979): 224-242.

14. John Barber, "Stalin's Letter to the Editors of Proletarskaya Revolyutsiya," Soviet Studies, 28, 1 (January 1976): 21-41. 
reviews in Pravda in December 1931 and January 1932, casting Shliapnikov's interpretation as Menshevik, as having elevated the role of the bourgeoisie and minimized that of the proletariat. Shliapnikov protested, accusing the editors of not understanding what they read, pointing out that previous editors saw nothing wrong with his books and insisting that the editors had not proven their charges. ${ }^{15}$ On February 19, the Orgburo summoned Shliapnikov to attend a meeting at which his books and his party history were excoriated not only by Orgburo members, but also by others invited from the $\mathrm{CCC}, \mathrm{Ob}^{\prime \prime}$ edinennoe gosudarstvennoe politicheskoe upravlenie (OGPU), and the Institute of Red Professors. His attempts at selfdefense were received as further confirmation of his guilt. ${ }^{16}$ In the name of the Central Committee, the party Organizational Bureau (Orgburo) resolved to stop publishing and distributing Shliapnikov's works and to require that he acknowledge his errors in them or be expelled from the party. ${ }^{17}$ Two days later, in a letter to his friend Aleksandra Mikhailovna Kollontai, Shliapnikov complained of "medieval" forms of criticism of his books, which he nevertheless was determined to continue writing, despite knowing that they were "already out of fashion" and "without any real hope that [they] will see light anytime soon."18

After the Orgburo session, Shliapnikov wrote to the Politburo to dispute the Orgburo's accusations against him and his books. First pointing out that Lenin had not objected to the books, he protested that some in the Orgburo criticized his books without having read them and that some criticizing him there had not even been Bolshevik party members in 1917. Despite Shliapnikov's request that the Politburo change the Orgburo's decision and give Shliapnikov the opportunity to eliminate from his books places that allow "incorrect interpretation," 19 on March 3, 1932, the Politburo confirmed the Orgburo's decision and gave Shliapnikov five days to comply. ${ }^{20}$ Shliapnikov's response, a March $6^{\text {th }}$ statement to the Central Committee,

15. G.I. Zlokazov, "Ne vse u retsenzentov iskhodit ot nevezhestva" [Not everything from reviewers comes from bad manners], Istoricheskii arkhiv, 3 (1994): 196-211. This reprints Shliapnikov's letter to the editorial board of Pravda in January 1932. Pravda editors' February 6, 1932 letter to Orgburo is preserved in RGASPI, f. 589, Party Control Commission, op. 3 , d. 9103, A.G. Shliapnikov, vol. 3, 1. 88-96, and has been published in L.N. Demidionova and I.A. Shliapnikova, eds., "'Gnusnyi paskvil' na partiiu': dokumenty TsK VKP(b) o vospominaniiakh A.G. Shliapnikova 'Semnadtsatyi god"' ['Vile libel toward the party': VKP(b) documents on A.G. Shliapnikov's memoirs Semnadtsatyi God], Istoricheskii arkhiv, 2 (1997): 123-124.

16. Shliapnikov's notes from this meeting (which apparently was not recorded by a stenographer) have been published in "'Gnusnyi paskvil' na partiiu'," 103-125.

17. RGASPI, f. 17, CC, op. 3, Politburo, d. 874, p. 15, Orgburo decision, February 19, 1932.

18. RGASPI, f. 134, A.M. Kollontai, op. 1, d. 437, 1. 30-31, Moscow, February 21, 1932. I have discussed the longstanding relationship between Shliapnikov and Kollontai in "A Proletarian from a Novel': Politics, Identity, and Emotion in the Relationship between Alexander Shliapnikov and Alexandra Kollontai, 1911-1935," The Soviet and Post-Soviet Review, 35, 2 (2008): 163-191.

19. RGASPI, f. 589, op. 3, d. 9103, vol. 3,1. 82-87, typed and signed letter from Shliapnikov to the Politburo, February 26, 1932, published in “'Gnusnyi paskvil' na partiiu'," 114-118.

20. RGASPI, f. 17, op. 3, d. 874, Politburo protocol 90, March 3, 1932, p. 2. This was published in Getty and Naumov, The Road to Terror, 105-106. 
acknowledged errors in his memoirs of 1917, but changed the wording of the Orgburo's accusations significantly. Thus, Shliapnikov made his errors appear less grievous. For example, instead of the Orgburo's assertion that he had "denied the hegemony of the proletariat", Shliapnikov wrote that he had poorly formulated his ideas, thus giving rise to the conclusion that he had denied the proletariat's hegemony. Nevertheless, the "confession" as it appeared in Pravda on March 9"th changed Shliapnikov's nuanced wording to a cruder and more thorough repentance. ${ }^{21}$ Subsequently, secondary and tertiary literature has gone so far as to interpret the March 1932 statement as a repudiation of all Shliapnikov's former oppositional stances in party discussions. In fact, the original statement signed by Shliapnikov was not even a complete repudiation of his memoirs.

\section{Minor political episodes of late 1932}

In June 1932, several months after his books were banned, Shliapnikov received an appointment as a member of the presidium of Gosplan RSFSR, as director of the construction sector (stroisektor). Although this was not a position of great responsibility, it attested that party leaders wanted to employ Shliapnikov in some capacity. Nevertheless, episodes later that year testified to Shliapnikov's insecure position within the party. In the fall of 1932, the CCC questioned his friend and former co-leader of the Workers' Opposition, Sergei Pavlovich Medvedev, about Martemian Nikitich Riutin's circulation of a treatise criticizing collectivization and attacking Stalin's leadership. ${ }^{22}$ Shliapnikov and Medvedev had often been the joint target of CCC investigations in the past. Shliapnikov, who was in Kislovodsk on vacation, wrote to Medvedev that no one there had seen Riutin's platform, but that diverse rumors circulated about it. He wrote, "The Riutin affair and others were received as a sensation." Moreover, he reported talk of "reform" among senior and midlevel bureaucrats vacationing in Kislovodsk, as they took walks in the park. Shliapnikov did not report participating in such talks, but in writing to Medvedev, he expressed skepticism about the affair, commenting that the "group" seemed more like a "conglomerate" and that "on the whole affair lies the stamp of hurry and lack of completion." The press reported that Vasilii Nikolaevich Kaiurov was supposed to provide a link with the Workers' Opposition. Shliapnikov wrote that in the CCC they must know that Kaiurov was never involved in the Workers' Opposition, but that "to someone it was interesting to 'link' us, but not successfully."23

21. “'Gnusnyi paskvil' na partiiu'," 123-124 (Shliapnikov's March $6^{\text {th }}$ statement to the CC), and 104 (preface by L.N. Demidionova and I.A. Shliapnikova).

22. TsA FSB, R33718, d. 499061 (materials on the accusation of the "Workers' Opposition," Moscow group, 56 vols.), vol. 42 (materials confiscated from S.P. Medvedev), 1. 203-205, Medvedev's notes about an October 25, 1932 meeting with E.M. Iaroslavskii.

23. Ibid., vol. 43 (materials confiscated from S.P. Medvedev), 1. 205, letter from Shliapnikov to Medvedev, October 16, 1932. 
In late 1932 and early 1933, Shliapnikov came to the attention of the CCC through a housing dispute in the residential cooperative where he lived and in which he was an elected administrator. After a cooperative member, Dr. Klinkovshtein, was arrested on political charges, two rooms in Klinkovshtein's apartment were given to a party official, Volkov, outside of the formal process and by means of intervention from CC members. When Klinkovshtein returned with permission to live in Moscow, he appealed for return of the rooms. Shliapnikov and other cooperative administrators, as well as court officials, attempted to follow established official procedures in settling the matter, whereupon Volkov accused Shliapnikov of defending a counterrevolutionary element. The CCC rebuked Shliapnikov and others for committing a political mistake. Emel'ian Mikhailovich Iaroslavskii changed the decision to a rebuke only to Shliapnikov and a warning to all others. ${ }^{24}$ Before the affair was over, it had become so tense that a courtyard dispute between Shliapnikov and a drunken guest of Volkov, about the guest having parked his car illegally, ended up before the CCC. Despite the character references Shliapnikov presented not only for himself but also for his German shepherd puppy (accused of menacing Volkov's guests), Iaroslavskii again assigned primary responsibility for the dispute to Shliapnikov. ${ }^{25}$

\section{Gosplan RSFSR: Shliapnikov's speech about the January 1933 CC plenum}

The next significant episode leading up to Shliapnikov's purge occurred in January 1933, when Shliapnikov was pilloried for remarks he allegedly made at a January $27^{\text {th }}$ Gosplan RSFSR party cell meeting. Shliapnikov disputed the recorded version of his remarks. On January $27^{\text {th }}$ and $28^{\text {th }}$, the party cells of Gosplan RSFSR and of Upravlenie narodnokhoziaistvennogo uchëta (UNKhU) RSFSR met to discuss the results of the January CC plenum. ${ }^{26}$ Mikhail Ivanovich Rogov, chair of Gosplan RSFSR, gave the chief report on the $27^{\text {th }} .27$ There was no verbatim transcript of the meeting, but a cell secretary took notes from Shliapnikov's speech. ${ }^{28}$ Shliapnikov had

24. RGASPI, f. 589, d. 9103, vol. 5,1. 214-229.

25. Ibid., 1. 146-176.

26. TsAODM, f. 390, Gosplan RSFSR, op. 1, d. 8, "Materials relating to Shliapnikov's antiparty speeches", 1.1. 109 members and 12 candidates were in the cell. Of those, 86 members and 6 candidates attended on January $27^{\text {th }}$ and 83 members and 8 candidates on January $28^{\text {th }}$. In the presidium were Rogov, Solovev, Golikov, Chuprakov, Kartashev, and Kuliabichev. In addition, Meteletskaia and Igonina from Mosgorkom and Vinogradov and Borodkin from Bauman raikom attended on January $28^{\text {th }}$.

27. RGASPI, f. 589, op. 3, d.9103, vol. 5,1.371-375.

28. According to TsAODM records, Kuliabichev took notes, but Shliapnikov accused Chuprakov of having authored a distorted version of Shliapnikov's January $27^{\text {th }}$ speech. In a letter appealing his purge in summer 1933, Shliapnikov alleged that the speech attributed to him in January 1933 at the Gosplan RSFSR party cell meeting was composed by "the technical secretary of the cell and member of the cell bureau Chuprakov, trying to escape the purge, a former officer now excluded from the party." (RGASPI, f. 589, op. 3, d. 9103, vol. 5, 1. 56-59; and TsA FSB, R33718, d.499061, vol. 14 (material evidence confiscated from Ivan Ignat' evich Nikolaenko), 1. 92-99, both copies dated July 20, 1933.) 
not prepared a copy of the speech, because his remarks were impromptu. He had not planned to speak, but a member of the cell, M.N. Smirnov, had advised him that he was expected to say something. Immediately after Shliapnikov spoke, he left to attend another event, so he was not present to rebut criticism of his speech. ${ }^{29}$

Among the controversial things Kuliabichev on the $27^{\text {th }}$ recorded Shliapnikov as saying, were: 1) that he would discuss political questions in his speech to provide an instructive example to the younger members on how to do so; 2) that the October Revolution gave nothing to the bedniak (poor peasant); and 3) that discussion within the party was acceptable and that he would participate in discussion if the party would allow it before the next congress. After Shliapnikov's departure, Smirnov and Luppov condemned his speech. They interpreted point 3 of Kuliabichev's notes to mean that Shliapnikov approved of individual disagreement with party decisions. Luppov called on others to criticize Shliapnikov, but the next several speakers either did not answer the call or did so only half-heartedly. At that point, the chairman, Golikov, postponed the meeting until the following day. ${ }^{30}$

On the $28^{\text {th }}$, Shliapnikov left his office in mid-afternoon to run errands. As he made his way home in the evening, a party organizer at Gosplan RSFSR, Kalmykov, caught up with him and asked him to return to Gosplan, since there were speeches against him in the party cell. At the cell, Shliapnikov was presented with a version of the speech he had given on the $27^{\text {th }}$, which he insisted was incorrect. ${ }^{31} \mathrm{~A}$ few days later, he reconstituted from memory his speech of the $27^{\text {th }}$ and sent it to the Gosplan RSFSR party cell. In his version, he expressed support for party policy on collectivization and industrialization and condemned the RiutinSlepkov and Eismont-Tolmachev-Smirnov groups. When referring to his past oppositional struggle, he insisted that he did not violate partiinost ${ }^{\prime}$. Furthermore, he agreed that party members must implement plenum decisions like military orders. Mentioning conversations in the corridor during the meeting, he expressed disapproval of these. Rather than holding hallway discussions that could lead to factionalism, he said that it was preferable to discuss doubts in the party assembly. His reference to hallway conversations risked exposing to criticism cell members, who might have condemned him in order to escape condemnation themselves. He said that when he compared the politotdely (political sections) being created under collectivization to those that were created during the civil war, he had specified their creation under "different conditions". Clarifying his thoughts on the bednota, he said that the aid it received from the soviet government before collectivization did not help it emerge from poverty, but that collectivization offered more

29. TsAODM, f. 390, op. 1, d. 8, 1. 88 and RGASPI, f. 589, op. 3, d. 9103, vol. 5, 1. 366-367, February 3, 1933 letter from Shliapnikov to the Gosplan RSFSR party cell bureau, to Bauman raikom and to the Moscow city party committee (Mosgorkom). Shliapnikov went to a meeting of the Astrakhan civil war zemliachestvo at the House of the Red Army.

30. TsAODM, f. 390, op. 1, d. 8,1.1-5.

31. Ibid., 1. 88 and RGASPI, f. 589, op. 3, d. 9103, vol. 5, 1. 366-367, February 3, 1933 letter from Shliapnikov to the Gosplan RSFSR party cell bureau, to Bauman raikom and to Mosgorkom. 
promising results. ${ }^{32}$ Shliapnikov's post factum rendering of his speech might not have precisely reflected what he actually said at the meeting; perhaps he clarified his remarks after taking into consideration the criticisms he had already heard.

On the $28^{\text {th }}$, eight speakers harshly criticized Shliapnikov, while eight criticized him mildly and ten said nothing at all about him. Meteletskaia of the Moscow city party committee (Mosgorkom), who criticized Shliapnikov especially harshly, complained that "former oppositionists" had "insufficiently rebuffed" Shliapnikov's speech. ${ }^{33}$ When Shliapnikov responded to criticism, he allowed that he might have spoken unclearly and have been misunderstood. Nevertheless, he denied having said what others had attributed to him. Asserting that he had had no differences with the party since 1927, he challenged his critics to provide evidence that he had doubted party policy on collectivization or the five-year plans. Emphasizing that in the past, he only participated in discussion of party decisions when the party allowed it, he insisted that he did not violate party statutes. When asked whether the party could trust him, he responded that party members should be trusted if there was no proof that they had conducted work against the party. ${ }^{34}$ Shliapnikov's interpretation of party legality ran counter to that which prevailed among Stalinists.

Those present unanimously accepted a unified proposal that approved the CC plenum's decisions and condemned Shliapnikov for making "antiparty assertions," for "not giving full criticism to his former mistakes," and for not providing "a clear party evaluation of counterrevolutionary group Eismont-Smirnov and others." Further, it was resolved that he should no longer lead his kruzhok (circle) on study of the January plenum's decisions. Corrections were accepted condemning the former oppositionists Garshenin and Itkin ${ }^{35}$ for not having criticized Shliapnikov, but these were not unanimous. ${ }^{36}$ Meteletskaia, a hardliner, reported to the CCC on the January $27-28^{\text {th }}$ assemblies. She accused Shliapnikov in vivid Stalinist vocabulary of making "antiparty errors" in his speech on the $28^{\text {th. }}$ Moreover, she was incensed that some party members did not condemn Shliapnikov in their speeches. She had proposed the condemnation of all those who did not comment on Shliapnikov's speech, but was not successful. The final resolution was far milder, targeting only Garshenin and refusing to remove him as leader of his kruzhok.

32. RGASPI, ibid., 1. 368-370 and TsA FSB, d. 499061, vol. 14, 1. 16, "Osnovnye momenty iz rechi tov. Shliapnikova” [Principal moments from comrade Shliapnikov's speech.]

33. TsAODM, f. 390, op. 1, d. 8,1.1-5.

34. RGASPI, f. 589, op. 3, d. 9103, vol. 5, 1. 378-382. This was personally verified and signed by Shliapnikov and Golikov on February 1, 1933. Shliapnikov made a few minor corrections. One of his corrections was to strike out the words "I have waged factional struggle since 1906."

35. According to some versions, Garshenin was a Trotskyist and according to others a Zinovievist. Itkin was presented consistently as a Trotskyist. In addition, Garshenin's name was sometimes spelled "Gorshenin."

36. TsAODM, f. 390, op. 1, d. 8, 1. 1-5; RGASPI, f. 589, op. 3, d. 9103, vol. 5, 1. 377, excerpt from resolution of general closed meeting of party assembly of Gosplan and UNKhU cells, January 27-28, 1933. Shliapnikov abstained from the vote (see Meteletskaia's report). 
Meteletskaia complained that the cell was rotten with "Philistine conciliationist moods." 37

In his appeal of the cell's decision regarding him, Shliapnikov noted that those who had spoken most sharply against him, the Bauman raikom representatives and Mosgorkom instructors, had not even been present on the $27^{\text {th }}$. He subverted the Stalinists' language, asserting that when Meteletskaia distorted his January $28^{\text {th }}$ speech, she was "unmasked" - the cell "rebuffed" her. Shliapnikov usually did not use such language, but employed it sardonically here. Insisting that he had been condemned on the basis of an incorrect protocol, he added for corroboration the admission of Golikov, the cell secretary, that the protocol had been "conducted inattentively and that others could not recognize their speeches according to it." Finally, he proposed a motive for the false accusations - that some of his accusers might have attributed to him "their own thoughts" in order to offer them for consideration "in the guise of struggle with them." As an example, he pointed to the rendering of his views on the bedniak. Another example pertained to politotdely under the machine tractor stations. Shliapnikov said that on the $28^{\text {th }}$, some had falsely accused him of saying that "in creating the politotdely, the party wants to wage civil war with the whole peasantry." 38

Shliapnikov's appeal was considered at a February $15^{\text {th }}$ meeting of the bureau of the Gosplan RSFSR party cell with the party activists (aktiv), where Shliapnikov requested that his own version of his January $27^{\text {th }}$ speech be entered into the official protocol of the assembly on the $27^{\text {th }}$. Rather than agreeing to recognize Shliapnikov's version as correct, the bureau unanimously resolved to request that Shliapnikov revise his version of his January $27^{\text {th }}$ speech to state that he desired to participate in pre-congress party discussions and to include the phrase, "anti-Marxist conversations and thoughts [are] not dangerous for the party at assemblies." 39 There is no evidence that Shliapnikov acceded to the bureau's request.

Shliapnikov made two speeches on February $15^{\text {th }}$ and responded to questions. He called the distortions of his speech ridiculous, since anyone who knew his past positions would realize he was usually criticized for saying the opposite of what was ascribed to him in the distorted version (regarding the peasantry, for example). Significantly, he also reproved his accusers for not having a sense of humor about some of his statements, which were meant in jest; thus, Shliapnikov contested the increasing suspicion with which gentle irony was viewed in Stalinist party circles. Insisting that the version restored by him be placed in the protocol of the January $27-28^{\text {th }}$ meetings in place of the distorted version, he exclaimed, "This is the established right of each party comrade and until now, nowhere has it been called into question." Calling on his knowledge of established party procedure, he said it

37. RGASPI, f. 589, op. 3, d. 9103, vol. 5, 1.371-375.

38. TsAODM, f. 390, op. 1, d. 8, 1.88 and RGASPI, f. 589, op. 3, d. 9103, vol. 5, 1. 366-367, February 3, 1933 letter from Shliapnikov to the Gosplan RSFSR party cell bureau, to the Bauman district party committee (raikom) and to Mosgorkom.

39. RGASPI, f. 589, op. 3, d. 9103, vol. 5,1.360, excerpt of protocol. 
had always been the custom in the party to present the stenographic record to the speakers and allow them to verify and approve it: "Even a stenographic record can only serve as a document after it has been signed." He professed not to understand why he was being pressured to recognize mistakes from the period of the Tenth and Eleventh party congresses in 1921 and 1922: "What do you want to achieve by working over these things now... I am supposed to explain each? I was sent here for work and not for an ordeal." ${ }^{40}$ Here, as in a 1932 letter to Kollontai, he implied that some within the party were applying medieval methods. Thus, he distanced his own Bolshevism from theirs and upheld rather more liberal standards.

\section{The Purge}

Shliapnikov met with four levels of purge commissions (cell, raion, oblast, and central). In Shliapnikov's case, members of higher-level commissions participated in the proceedings of lower level commissions and vice versa. Some of the proceedings were open to spectators (almost certainly the cell-level purge session was), including people who were not members of the party. This was also customary, as the purge sessions were supposed to provide lessons to a broader party and sometimes nonparty audience. ${ }^{41}$ Therefore, it must be considered that when Shliapnikov and commission members were speaking, it was not only to one another, but to a wider audience.

In Gosplan RSFSR, the party purge began on June 8, 1933. According to commission chair Ivanov, Shliapnikov was present on that day and spoke about how earlier purges had been conducted. ${ }^{42}$ Although he was to undergo the purge that day, he left early and did not appear for the purge on the second day, providing a doctor's note and asking to postpone his purge due to illness. Ivanov reported that Shliapnikov had told others that the CCC would purge him, not the cell.43 Nevertheless, Shliapnikov's Gosplan RSFSR purge session was held on June 17, 1933. Ivanov chaired; Antropov and Shillert were also members. Iakov K. Peters and Aaron Aleksandrovich Sol'ts from the Moscow oblast commission also participated. ${ }^{44}$ Those carrying out the purge intended for Shliapnikov to discuss moments when he

40. Ibid., 1. 361-365. Shliapnikov personally verified and signed this transcript of his speech.

41. Simon Pirani noted audiences of non-party workers at cell purge meetings in 1921, in The Russian Revolution in Retreat, 1920-24: Soviet Workers and the New Communist Elite (London: Routledge, 2008).

42. Shliapnikov was in the CCC's 1921-1922 purge commission.

43. RGASPI, f. 589, op. 3, d. 9103, vol. 5, 1. 353-355, copy of a letter from Ivanov to Knorin, chairman of the oblast purge commission, undated. Knorin was probably Vil'gel'm Georgievich Knorin, who was director of the Institute of Red Professors in the 1930s and a member of the editorial board of Pravda.

44. Ibid., 1. 1-51, stenographic report of Gosplan RSFSR party cell assembly on the purge of Shliapnikov, June 17, 1933. 
had held minority views in party discussions and to prove his devotion to the party in 1933. Shliapnikov insisted that there was more to his party history than those moments of opposition. He spoke for almost two hours, with surprisingly few interruptions, about his childhood in a poor Old Believer family, his youth working in factories, and his party activities before 1917 . His account of his childhood was very similar to descriptions he had given of it on other occasions, except that he emphasized experiences of oppression even more strongly. Twice he compared tsarist oppression of him as an Old Believer and revolutionary to tsarist-era antiSemitism and to pogromist violence. Perhaps in emphasizing this comparison, he thought that it would elicit sympathy from some members of his audience. On other occasions, he recalled that some of those present at his purge had been in other parties before the revolution, while he himself was with the Bolsheviks.

Shliapnikov was determined to conduct the purge sessions as much on his own terms as possible. When Ivanov impatiently interrupted to remind him that he should describe how he "struggled with the party," Shliapnikov replied that he "struggled more with the capitalists." 45 As he recounted numerous adventures in the wartime revolutionary underground, Peters grew indignant: "You are talking history, telling all kinds of stories; all this is not what is needed for a purge." 46 Purge commission members pressed Shliapnikov to acknowledge that when in late 1917 he signed the letter from Sovnarkom members calling for the Bolsheviks to agree with other parties in the Soviet, he had rejected the dictatorship of the proletariat. Disagreeing, Shliapnikov pointed out that he did not resign from his post as Commissar of Labor. When Antropov demanded that he "give a political evaluation" of his mistake that would characterize it as "panic", Shliapnikov jokingly parried that he was not a person who was easily frightened. In another assertive moment, he scolded Peters for having a weak grasp of history. ${ }^{47}$

When the chairman insisted that Shliapnikov confine himself to the topic of his "struggle with the party," Shliapnikov drolly complained, "You're only interested in the negatives, but not in the positive things that I contributed to our party." Contrary to instructions, Shliapnikov proceeded to describe his military leadership during the civil war and his international trade union work. Refusing to vilify the Workers' Opposition, Shliapnikov maintained that it originated in opposition to Trotskii's proposals for militarization of industry and that its program was based on a paragraph in the party program allotting to trade unions the eventual management of production. Shliapnikov denied Antropov's accusation that the WO rejected the party's leading role and asserted that its only major mistake was failure to realize that trade union management of production was premature in the context of the early 1920 s. ${ }^{48}$ Since the WO's platform was proposed within the party, he insisted,

45. Ibid., 1. 33 .

46. Ibid., 1. 24-23.

47. Ibid., 1. 22-17.

48. When Shliapnikov said that "under the dictatorship of the proletariat the CC of the party leads industry," there was noise (shum) among attendees. This appears to be significant, but I 
that made it a party document. Thus, it was legal. He did not submit to attempts to coerce from him a Stalinist "political evaluation" of the WO; Shliapnikov reiterated that the WO program was mistaken because it was not realistic at the time. Furthermore, in attesting that he did not continue to promote the WO's platform after the Tenth party congress, Shliapnikov explained that he and the others had learned a lesson from the Tenth Party Congress: "Having arranged factional struggle, you cannot freely maneuver once it has ended. This is the logic of factional struggle. Therefore we learned a lesson, not to repeat factional groupings in the future." He refused to discuss Kollontai's brochure, insisting that it was written about the Workers' Opposition, but was not a document of the Workers' Opposition. ${ }^{49}$

Before the Eleventh party congress, Shliapnikov and some others had signed and sent the "Letter of the 22" to the Communist International (Comintern), protesting Russian Communist Party leaders' suppression of heterodoxy within the party. Despite pressure at the purge to call this act factionalism, Shliapnikov insisted it was only "group work." Although he acknowledged that the Eleventh Party Congress deemed the "Letter of the 22" a "factional act," Shliapnikov denied that he conducted factional work. As those present discussed the definition of factionalism, Ivanov opined that a faction did not have to be large, that only three people could constitute a faction. When in his defense, Shliapnikov pointed out that in 1922 at the $11^{\text {th }}$ Party Congress Sol'ts did not vote to exclude him for factionalism, the chairman Ivanov was disturbed. Nevertheless, Shliapnikov insouciantly continued, "I do not want to compromise comrade Sol'ts with the goodwill of his attitude towards me." Noise (shum) ensued. Although Shliapnikov seemed to be tiring, he did not let up on Sol'ts. When Sol'ts badgered him about representing his early 1920s activities inaccurately, Shliapnikov retorted that Sol'ts also knew how to conduct factional work in the 1920s. ${ }^{50}$

The commission members tried to link him with Trotskii, Grigorii Evseevich Zinov'ev, and Lev Borisovich Kamenev in the United Opposition, but Shliapnikov denied any connection. Other episodes, such as Shliapnikov's dealings with Gavriil

am not sure how. Perhaps Shliapnikov's allotment of a leading role to the CC rather than just the party was an unacceptable slip.

49. RGASPI, f. 589, op. 3, d.9103, vol. 5,1.16-12.

50. Ibid., 1. 12-4. On the next day, Shliapnikov explained in writing to the Gosplan RSFSR party cell purge commission chairman that he was reluctant to discuss all the details of the $11^{\text {th }}$ party congress' deliberations on the "Letter of the 22" at the purge session, because the deliberations had been at a closed session. Since most of the attendees at the purge session were not party members, he did not consider it permissible to enlighten them on the details. In this letter, he explained that Kamenev introduced the resolution to exclude Shliapnikov and others, but a majority rejected it. Subsequently, Mikhail Pavlovich Tomskii proposed that those mentioned in the resolution should get another chance, but be punished if they would act similarly in the future. RGASPI, f. 589, op. 3, d.9103, vol. 5,1.358, photocopy of a handwritten letter from Shliapnikov to chairman of Gosplan RSFSR purge commission, June 18, 1933. For more on the "Letter of the 22," see my article, "Early Dissent within the Party: Alexander Shliapnikov and the Letter of the Twenty-Two," The NEP Era: Soviet Russia 1921-1928, vol. 1 (2007): 21-54. 
Il'ich Miasnikov and Workers' Group in 1923 and Sergei Pavlovich Medvedev's 1924 letter to a Baku comrade were reviewed, as were Shliapnikov's political articles in intraparty discussions in 1924 and 1926. All accused him of not giving clear answers and Antropov finally introduced the charge of dvurushnichestvo (duplicity): "It seems you formally recognized the party line but actually conducted struggle against it, moreover it was factional struggle, isn't this dvurushnichestvo?" Defiantly, Shliapnikov insisted that it only appeared so if selected episodes were examined, but not if the entirety of his work were considered.51 The commission only touched upon his work in Gosplan RSFSR near the very end of the session. Shliapnikov admitted that he worked "very little" in Gosplan because of his deafness. Indeed, it is evident from the transcript that his hearing worsened during the course of the purge session. Despite his deafness and weariness, when Ivanov requested that he present a document "that would actually and fully criticize severely your position for the whole period of your struggle," Shliapnikov retorted, "No one has assigned me such literary works." In exasperation, Antropov asked, "Didn't you think of it on your own?" Bringing the session to a close, Sol'ts requested that someone characterize Shliapnikov's work in Gosplan, whereupon Shliapnikov asked to be excused because he felt ill and couldn't hear much. The chairman moved for a debate. ${ }^{52}$

The Gosplan RSFSR purge commission resolved to exclude Shliapnikov from the party for dvurushnichestvo. It found him guilty of diverging from the party ever since the October 1917 Revolution, asserted that he had "spoken together with Trotskyists and right opportunists," and accused him of having worked poorly at Gosplan RSFSR. ${ }^{53}$ In the 1920 s purges, party members purged for political reasons were often charged with "incompetence" in work. ${ }^{54}$ Shliapnikov's purge follows this same pattern; moreover, the transcript reveals that of all charges, the party cell purge commission spent the least time developing that of malfeasance in Shliapnikov's work.

Shliapnikov only received an excerpt of the purge commission's decision on July $15^{\text {th }}$. Before this, he read of its motivations for purging him in a Pravda article by Knorin, director of the party purge for Moscow oblast. On July 15, 1933, Shliapnikov appealed in writing directly to Stalin, hoping to bypass several more purge sessions and have the Politburo reconsider his purge from the party. Shliapnikov protested not only his exclusion from the party, but also a campaign against him in the party press (Moskovskii rabochii, Pravda), depicting him as a consummate double-dealer (zakonchennyi dvurushnik). Making his case for appeal, he explained that deafness had interfered with his ability to defend himself against the charges. In the past four months, he had been deaf in both ears more than $50 \%$ of the time. In June, doctors forbade him activity that could worsen his

51. RGASPI, f. 589, op. 3, d.9103, vol. 5, 1. 10-14.

52. Ibid.,1. 1-3.

53. Ibid., 1. 52, excerpt from protocol no. 7 of Gosplan purge commission, June 17, 1933.

54. David-Fox, Revolution of the Mind, 158. 
deafness. He reminded Stalin that he and Lazar' Moiseevich Kaganovich had assigned Shliapnikov to work in Gosplan, despite Gosplan RSFSR chair Rogov's cautions that there was not enough work for all presidium members. Shliapnikov defended his work as chief of the construction sector (stroisektor), as having placed that sector fifth among seventeen Gosplan RSFSR sectors in quality of work. Moreover, no one criticized his work until the purge campaign began. Stalin directed Shliapnikov's appeal to the Central Purge Commission ${ }^{55}$ and Shliapnikov was forced to appeal and undergo more questioning at every level.

Within a few days, Shliapnikov directed a letter of appeal to the Bauman raion purge commission. He protested a number of mistakes in the protocol, among them that it erred in stating that he had belonged to the German Democratic Party in 1912 (indeed, there was no such party; Shliapnikov had belonged to the German Social Democratic Party - SPD). Another mistake referred to him as having been leader of the Workers' Opposition still in 1933; he demanded evidence of this. Next, Shliapnikov disputed the commission's assertion that he "conducted struggle against the party" since October 1917 "without interruption." In his appeal, he detailed everything he did to help the party. Moreover, he depicted the trade union dispute as originally a struggle in which he stood together with Lenin and the CC majority against Trotsky. Only in the last two months of 1920, he wrote, did he go "on the path of factional pre-congress struggle." He denied having defended the Workers' Opposition after the Tenth party congress and denied having ever "spoken together" with Trotsky and other oppositionists. Pointing out that the party had continued to assign him work in the 1920s, he argued, "All my mistakes were committed by me within the party and were resolved in a party manner." $\mathrm{He}$ published articles promoting his views only in the party press. Therefore, his actions were not directed against the party. As in the letter to Stalin, he defended his work for Gosplan RSFSR and urged that purge commission members check the Gosplan RSFSR records for verification of his work..$^{56}$

Upon appeal, Shliapnikov's case proceeded to the Bauman raion purge commission. Again, Shliapnikov underwent questioning about his party history and defended himself from the charges the Gosplan RSFSR purge commission made against him. He did not repeat the life story he recounted at the first purge session, but dwelled on the period after 1917. Some of his answers indicate that he did not hear the questions clearly or precisely. ${ }^{57}$ Drawing distinctions between the Workers' Opposition and those who signed the "Letter of the 22," he insisted that the latter was not a continuation of the former. He made a concerted effort to refute the charges of continuity in his political struggle, pointing out that he only spoke out during times of political discussion within the party, and that factions were not

55. Copies of this letter are in RGASPI, f. 589, op. 3, d. 9103, vol. 5, 1. 53-54 and in TsA FSB, R33718, d. 499061, vol. 14,1. 17.

56. Copies of this letter are in RGASPI, ibid., 1. 56-59, and in TsA FSB, ibid., 1. 92-99. Both are dated July 20, 1933.

57. RGASPI, ibid., 1. 60-82. 
even formed around some of the documents he signed, such as that of the People's Commissars in 1917. Moreover, he insisted that his mistaken views had nothing to do with kulaks or "capitalist elements," for even when he had erred, he had done so in sincere belief that he was trying to "defend the workers." Surely, he argued, the fact that the party accepted the Workers' Opposition's proposals on improving workers' living conditions attested that he had not consistently been at odds with the party.$^{58}$ Investigations of him in the 1920s failed to find him guilty of factional struggle, he reminded the purge commission. 59

Defending his work in Gosplan RSFSR, he attributed distortion of his speech on January $27^{\text {th }}$ to "people who tried to cleanse themselves on the sins of others." Finally, he insisted that the Bauman commission misunderstood the nature of his work in Gosplan, that it was strictly involved in planning and was supposed to stay away from "operative" work. At last, the chairman interrupted Shliapnikov, told him he would be informed of the commission's decision, and dismissed him. ${ }^{60}$ The Bauman purge commission confirmed the Gosplan RSFSR purge commission's decision to exclude Shliapnikov from the party, changed the wording of its resolution to specify that he had been in the German SPD, added charges pertaining to his books on the history of the revolution, and stated that he should be excluded as someone who had "decisively broken with Bolshevism, who stays in the party because it is the only party and is in power."'61

After Shliapnikov heard of the Bauman commission's decision, he appealed to the Moscow oblast purge commission, writing that he attributed the "many deeply untrue accusations" in the Bauman commission's directive to incompetence, "malicious desire and personal enmity." Again, he referred to documents to refute the accusations and expressed indignation that the commission did not rely on documents when it accused him. Disavowing any links to Trotskyists or Rightists, he also refused to accept the commission's conflation of the two groups. Regarding his memoirs of 1917, he found it unnecessary to condemn him for these, as he already had acknowledged his mistakes in public. The commission, he wrote, engaged in "fortune-telling" when it interpreted his earlier declarations admitting mistakes as "double-dealing" undertaken in order to allow him to continue "attacks against the party" in the future. ${ }^{62}$

Shliapnikov's meeting with the Moscow oblast purge commission in early September 1933 began confrontationally, with Shliapnikov proclaiming that he was "especially upset" by the raion purge commission's depiction of him as if he were "still

58. Ibid., 1. 79-82.

59. Ibid., 1. 74-76.

60. Ibid., 1. 60-72.

61. Ibid., 1. 83-84. The chairman was Gei and members were Varlen and Leonov. Others, Ivanov and Gromov, spoke at the session with criticism of Shliapnikov.

62. Copies of this letter are in RGASPI, f. 589, op. 3, d. 9103, vol. 5, 1. 85-92 and TsA FSB, R33718, d. 499061, vol. 14. 
engaging in factional work." 63 In response, the commission members claimed that this wording arose from a typographical error that had been corrected, but that they did indeed regard him as still being in "divergence" from party policy. The conversation then turned toward discussion of how "divergence" could be determined. Shliapnikov demanded proof: "where are the documents?" His interrogators replied variously: that it was up to Shliapnikov to prove he was not in divergence (Karavaev) and that the purge commission was not a court (Peters). Shliapnikov disagreed, calling it a "party court."64 As before, Shliapnikov insisted, "I struggled within the party, not against the party." 65 Sol'ts clarified that it was not necessary "to prove by some juridical route" whether a member should be purged. Instead, the matter "is decided on the basis of party conscience (sovest)". Gei found fault with Shliapnikov for holding "juridical" rather than "political" conversations with the purge commissions, for defending himself rather than "disarming." For Gei, Shliapnikov's defensive stance was evidence in itself that he still held to his old views. ${ }^{66}$

Earlier in the meeting, Shliapnikov had asserted that if there were no documents proving the charges, then "personal enmity" must lie behind them. ${ }^{67}$ Peters called Shliapnikov a degenerate (pererozhdenets) for thinking so. Further, he assured Shliapnikov that his "appearance" did not "call forth enmity"; thus, any enmity he, Peters, felt, was "only according to party regulations." Shliapnikov drily replied, "That is very pleasant." 68 Sol'ts admitted to "extraordinary interest" in Shliapnikov's purge because Shliapnikov had a long party history, whereupon Shliapnikov asked Sol'ts if he knew Shliapnikov would be excluded and Sol'ts said he suspected so. Shliapnikov replied that he also suspected it. Sol'ts continued: "We live in such a grandiose period that if a party member does not show himself, he is not a party member. [...] [T]here is no Shliapnikov in the party, but there is a person, who is there, who does something, but not a party member. In such a time, in such a great time, about which we have dreamed so many years, comrade Shliapnikov ironically saunters around." He deemed Shliapnikov's complaints of illness and "weakened emotions" to be "trifles." Addressing Shliapnikov, Sol'ts proclaimed, "your heart is empty [...] each time I meet you, I become more convinced that you are hopeless and this worries me." 69

63. RGASPI, ibid., 1. 93-119, September 4, 1933. Present were Knorin, Peters, Karavaev, Sol'ts, [N. A.?] Filatov, and Ivanov. From the transcript, it appears that Shliapnikov often could not hear well. His responses were not always relevant to the questions and statements made by his interrogators.

64. Ibid., 1. 118-119.

65. Ibid., 1. 114.

66. Ibid., 1. 110-113. Molotov had likewise accused Tomskii of acting like a "cunning lawyer" when he defended himself in 1932 against charges of forming a group with Smirnov and Shmidt, but Tomskii had in the past used Stalinist language against the "United Opposition" (Wynn, "The 'Smirnov-Eismont-Tolmachev Affair'," The Lost Politburo Transcripts, 110-11).

67. RGASPI, f. 589, op. 3, d.9103, vol. 5, 11. 114-115.

68. Ibid., 1. 106-108.

69. Ibid., 1. 103-106. 
The conversation turned toward what Shliapnikov should be excluded for. Knorin proposed to designate Shliapnikov a Menshevik and "enemy of the party" outright, rather than "an inoffensive Philistine (meshchanin and obyvatel')," as some comrades preferred. Beyond simply confirming the Bauman raion commission's decision, he called for declaring Shliapnikov's appeal of his purge to be "an anti-party document."70 After hearing Knorin, Shliapnikov appeared to regard Peters and Sol'ts as holding milder positions. Therefore, he offered concessions to them, including showing more activism in the Moscow party organization. Spurning his offer, Filatov declared he had "entered a dead end street." Shliapnikov obstinately maintained, "I have been in the party 33 years. Half of them I have not had a party card. If I am deprived of a party card, then this will change nothing. I won't be different. I have no convictions that are not of the working class." When Filatov told him he was already different, Shliapnikov retorted, "If I am different, then I nevertheless am not you, but myself." At this point, Knorin told him he should leave, so that the commission could make a decision, and that he could appeal to the Central Purge Commission. ${ }^{71}$ After Shliapnikov left, Sol' ts insisted that the decision emphasize that Shliapnikov was being purged not only for the past, but also for the present. The others agreed. ${ }^{72}$ The final decision proclaimed that Shliapnikov "continues double-dealing" and “continues to defend the Workers' Opposition, which was born of trade unionist Menshevism," that his "appeal is a deeply antiparty document." Thus, it included Knorin's assessment of Shliapnikov's appeal and tainted the Workers' Opposition with Menshevism, but did not designate Shliapnikov as a Menshevik outright. ${ }^{73}$

The final court of appeal was the Central Purge Commission; Shliapnikov met with its secretariat on September 29, $1933 .{ }^{74}$ As the meeting began, Shliapnikov asked ironically why, if he really "conducted antiparty work for 16 years," as accused by the lower level purge commissions, the CC and CCC did not notice it. As before, his posture was defensive, regarding his politics and his work in Gosplan. ${ }^{75}$ Iaroslavskii held forth: "Shliapnikov still doesn't understand what is demanded of him as a party member [..] He says he was sick. [...] It's no misfortune if Shliapnikov lives one year less, but for that he would live as a party member (partiets), having corrected his behavior in the eyes of party members..."76

Ivanov, chairman of the Gosplan RSFSR party purge commission, claimed that Shliapnikov, unlike all others, was allowed to talk about his life for two hours at the

70. Ibid., 1. 97-100.

71. Ibid., 1. 94-96.

72. Ibid., 1. 93.

73. Ibid., 1. 120, September 10, 1933.

74. Ibid., 1. 122-144, September 29, 1933. Besides Shliapnikov, those who spoke were Shkiriatov, Iaroslavskii, Elena Dmitrievna Stasova, Ivanov, Shillert, Sol'ts, Ezhov, and Knorin. I did not find a written appeal from Shliapnikov to the Central Purge Commission.

75. Ibid., 1. 140-144.

76. Ibid., 1. 139. 
purge. He regretted that Shliapnikov's assistant Shcherbakov refused to criticize Shliapnikov's work in the stroisektor. He noted that Shcherbakov was "raked over the coals" (vzgreli) for this at the purge. ${ }^{77}$ Perhaps this was to excuse Gosplan RSFSR's weak case against Shliapnikov's work performance. In the context of the times, Shcherbakov's loyalty to Shliapnikov was personally very risky; perhaps it was testimony to Shliapnikov's personal qualities, as well as to the strength of the cronyism or nepotism (semeistvennost') ${ }^{78}$ within Gosplan RSFSR. Shillert, Matvei Fëdorovich Shkiriatov and Sol'ts all rebuked Shliapnikov for not having taken initiative to criticize his past mistakes sufficiently and for not having behaved in a way suiting a party member. Shliapnikov objected, "Comrade Sol'ts! I don't know how personally interested you are in the party, but I think that I do not lag behind you in questions of party policy." 79 Shliapnikov attributed some of his mistakes to "pride" and the "ability to defend" himself. Finally, however, he humbly requested that they help him "get onto the path." 80

At this point, Nikolai Ivanovich Ezhov, a party member whose career was on the ascendancy, intervened and spoke at length. ${ }^{81}$ Emphasizing that recognition by Shliapnikov of errors in the past had always been followed by new errors, he condemned Shliapnikov for having insufficiently "fought for the party's general line." Condescendingly, he pointed out that the party was "patient" toward Shliapnikov because he was "an old party member, a worker, a cultured worker" on whose "upbringing" the "party spent a lot." Acknowledging that Shliapnikov had also worked hard ("svoim gorbom") and had accomplished feats such as writing books, that were beyond many workers, Ezhov nevertheless accused Shliapnikov of "constantly abusing" the party's patience by using his talents and strength "only in struggle against the party." For Ezhov, the need to "bring up young party members in the correct spirit" clinched Shliapnikov's exclusion from the party. ${ }^{82}$

\section{Ibid., 1. 136 .}

78. On semeistvennost' and patron-client relations, see Sheila Fitzpatrick, "Patrons and Clients," Tear Off the Masks!: Identity and Imposture in Twentieth-Century Russia (Princeton, NJ: Princeton University Press, 2005); T.H. Rigby, Political Elites in the USSR: Central Leaders and Local Cadres from Lenin to Gorbachev (Aldershot: Edward Elgar, 1990); and Graeme Gill, The Origins of the Stalinist Political System (Cambridge: Cambridge University Press, 1990).

79. RGASPI, f. 589, op. 3, d.9103, vol. 5, 11. 131-135.

80. Ibid., 1. 129-130.

81. Ezhov at this time was a CCC member. His leadership in the purge campaign would lead to his appointment as deputy chairman of the Party Control Commission in 1934 and as its chairman in 1935 (Getty and Naumov, Yezhov). In 1936, he became head of the NKVD. Ezhov had a personal connection with Shliapnikov. In his youth, he had lived with some of Shliapnikov's relatives and received work with their help. In addition, I have seen documents indicating that in the early 1920 s, he had personal friendships with some supporters of the Workers' Opposition.

82. A.N. Iakovlev, ed., Reabilitatsiia: politicheskie protsessy 30-50-kh godov [Rehabilitation: political processes of the 1930s-1950s] (M.: Politizdat, 1991), 104-22; "Moskovskaia kontrrevoliutsionnaia organizatsiia - gruppa 'rabochei oppozitsii"' [Moscow counterrevolutionary organization — the Workers' Opposition group], 115-116. 
At the end of his speech, Ezhov agreed with Shliapnikov's exclusion from the party, but allowed that Shliapnikov might "improve" and might "prove this by his actions," so that he might enter the party again in the future. 83

Shliapnikov's concessions at this later stage of the purge emerged from his extreme exhaustion and illness. His final words revealed the toll the purge had taken on his health and state of mind:

If you consider that I possess some sort of capabilities and am needed by the party, that I am not ballast, then I ask you to help me to get onto the path. My nerves are sufficiently shattered. Do you think it is easy to endure this nervous strain? I am losing my hearing. You know about my moral state. [...] I consider that I am completely not such as I am exposed as being [...] I do not think of myself as outside the party and no matter what your decision is, I will remain a member of the party. [...] I will do all. Members of the commission will become convinced of this, if they will vote for me to remain within the party. Goodbye. I hope to meet with you as a party member. ${ }^{84}$

The central purge commission confirmed Shliapnikov's exclusion from the party as a dvurushnik and a pererozhdenets, guilty of "Menshevik vacillations." 85

\section{Conclusion}

Shliapnikov suspected that his exclusion was inevitable, yet he struggled determinedly to refute the accusations against him. First, he preserved a spark of hope that he would not be excluded; indeed, there had been many aborted efforts to exclude him in the past. Second, he intended to confront individuals who knew him, forcing them to make personal choices about his exclusion. Third, he intended to create a record refuting the charges against him, for history and for political purposes. Fourth, perhaps he thought there was some room in which to negotiate the terms of his exclusion and create the possibility for restoration of his party membership. Indeed, Ezhov seemed to hold out that possibility. Although Shliapnikov's purge surely was a foregone conclusion, the transcripts of the purge sessions appear to indicate some indecision and negotiations among purge commission members as to the terms on which Shliapnikov should be excluded. Nevertheless, at each level the charges became more serious and more encompassing. Interrogators at each level could not show complacency by preserving the same charges, but were expected to demonstrate their activism and

83. RGASPI, f. 589, op. 3, d. 9103, vol. 5,1. 125-126.

84. Ibid., 1. 122-123.

85. Ibid., 1. 145, November 1, 1933, excerpt from protocol of Central Purge Commission on October 31, 1933. Knorin gave the report on Shliapnikov's case and attending were also Shliapnikov, Ivanov, Shillert, Mochalov (member of Gosplan RSFSR party cell bureau), Sol'ts (member of Moscow oblast purge commission), and Karavaev. Iaroslavskii was secretary of the Central Purge Commission. 
commitment by adding more. Shliapnikov could not bring himself to perform the humiliating ritual of self-abasement that the Stalinists required. Moreover, his selfdefense was not conducted in the Stalinist manner; rather than attempting to internalize Stalinist values and repudiate his past politics, he provided evidence of having defended the party's interests and of having criticized only within the framework allowed by the party. He tried to revive the lightly ironic humor that had permeated party gatherings in the 1920s and earlier. More seriously, he offered himself to the party as a worker, as an organizer, who could contribute something of practical value. This was the mindset of the "workerist" element among the Bolsheviks, which differed from the "eschatological" strain. Shliapnikov was secure in his identity as a proletarian; thus, he did not have as great a psychological need to explore his "soul," as did Iaroslavskii and other party intellectuals. ${ }^{86}$

\section{Epilogue}

Among the many other former Workers' Oppositionists purged in 1933 was Shliapnikov's close friend Sergei Medvedev, whom the Moscow oblast commission purged in November 1933. Since Medvedev did not belong to a party cell in 1932 and his membership papers had been lost, he was purged later than many others. Unlike Shliapnikov, Medvedev declined to say much on his own behalf at the purge, telling Sol'ts and Karavaev that they must already know enough about him from earlier CCC investigations. He only explained that he did not belong to a cell because his paperwork had been lost and no one wished to issue him new paperwork attaching him to a cell. ${ }^{87}$ This might have reflected the known troubles that followed former oppositionists and that had the potential to draw suspicion toward their fellow cell members. Upon learning of Medvedev's purge, Shliapnikov sent him a letter from Kislovodsk, where Shliapnikov was on vacation. Attempting to cheer up Medvedev, he mocked charges in the press that Medvedev, even while standing in the reserves, had undermined the work of the Commissariat of Heavy Industry, headed by Grigorii Konstantinovich (Sergo) Ordzhonikidze. ${ }^{88}$

Not long after his purge, Medvedev was sent into administrative exile to Karelia to work on the White Sea-Baltic Sea Canal. Shliapnikov encouraged him to appeal his exclusion from the party, but Medvedev replied pessimistically, "However bitter it is to recognize that there is no return for us to the past, we must recognize this indisputable fact! I cannot find a place in my consciousness for the thought that without the vilest self-abasement we can be rehabilitated..." Medvedev explained the purge and other recent political events within the party as "a delayed episode of

86. I am grateful to Anna Krylova for raising this point at the 2007 AAASS panel on which this paper was presented.

87. TsA FSB, R33718, d. 499061, vol. 42 (materials seized from S.P. Medvedev upon his arrest in 1935), 1. 201-202, 275-276. His purge session was on November 22, 1933; Sol'ts (chair), Karavaev, Filatov, Medvedev and a stenographer attended.

88. Ibid., vol. 43 (materials seized from Medvedev), December 9, 1933. 
political struggle within the country," unfortunately without elaborating upon what he meant by this ${ }^{89}$ In early 1934, Shliapnikov was briefly exiled administratively to Karelia; in a diary, he described the manner in which he was exiled, the extralegality of which perplexed him. He also wrote nuanced assessments of his interactions with various types of people (administrators of the Narodnyi komissariat vnutrennykh del (NKVD), prisoners, administrative exiles) on his journey to Karelia..$^{90}$

Both Shliapnikov and Medvedev were arrested in January 1935, in the wake of the Kirov assassination. They were held and interrogated on numerous occasions and at length by the NKVD in Moscow. Interrogation transcripts show that Shliapnikov contested the charges against him, not only orally but also by making changes and additions to the transcripts in his own hand. Shliapnikov was sentenced to five years in a labor camp, which was commuted to exile in Astrakhan at the end of 1935. He was rearrested in 1936, imprisoned, interrogated, and tried and executed in September 1937. At his closed trial by a military tribunal, Shliapnikov confessed only to having harbored "a liberal attitude" toward those surrounding him. ${ }^{91}$

History Department, La Salle University

allenb@lasalle.edu00

89. Ibid., vol. 14, various materials in a packet behind list 108.

90. Shliapnikov's diary describing his internal exile was published as "My ne reshaem nyne dazhe svoei sud'by" [We do not decide now even our own fate], Istoricheskii arkhiv, 1 (2002): 3-31.

91. I have analyzed one aspect of NKVD interrogations of Shliapnikov in "Friendship in Times of Factionalism and Terror: Aleksandr Shliapnikov and Sergei Medvedev," Revolutionary Russia (London, England), 20, 1 (June 2007): 75-93. My biography of Shliapnikov (in progress) will discuss more fully the NKVD interrogations of him and Medvedev. 